\title{
Araucaria araucana and the Austral parakeet: pre-dispersal seed predation on a masting species
}

\author{
El pehuén y la cachaña: depredación predispersión de una especie "masting"
}

\author{
JOHN D. SHEPHERD ${ }^{1 *}$, REBECCA S. DITGEN ${ }^{1} \&$ JAVIER SANGUINETTI $^{2}$
}

\author{
${ }^{1}$ Department of Biology, College of Liberal Arts, Mercer University, Macon, Georgia 31207, USA \\ ${ }^{2}$ Administración de Parques Nacionales, Parque Nacional Lanín, Emiliano Frei 749, 8371 San Martín de los Andes, \\ Neuquén, Argentina \\ *e-mail for correspondence: SHEPHERD_JD@Mercer.edu
}

\begin{abstract}
Pre-dispersal seed predation by Austral parakeets, Enicognathus ferrugineus, on pehuén, Araucaria araucana, was studied to assess the relationship between predation and seed production. We collected falling seeds in four araucaria forests of southwestern Neuquén Province, Argentina during four years that included both mast and intermast years. Predation rates were negatively correlated with seed production. When seed production was high, predation rates ranged from 0.6 to $3.3 \%$; when it was low, predation rates ranged from 13.0 to 20.6 $\%$. Years differed in the pattern of monthly seed fall with peak seed fall in March 2002 and April 2003. Predation rates were lower and more uniform in the year of higher seed production, but did not differ between sites. In an intermast year, predation rates increased during the season, reaching their highest rates after peak seed fall. Parakeets handled seeds differently in mast and intermast years, dropping fewer slightly-damaged seeds when production was low. We discuss these results in the context of the predator satiation hypothesis.
\end{abstract}

Key words: pre-dispersal seed predation, masting, Araucaria araucana, Enicognathus ferrugineus

\section{RESUMEN}

Se estudió la depredación predispersión de semillas del Pehuén, Araucaria araucana, por la cachaña, Enicognathus ferrugineus, para evaluar la relación entre depredación y producción de semillas. Durante cuatro años, incluyendo años de alta ("semillazón") y baja producción de semillas, se colectaron semillas caídas de los árboles en bosques del sudoeste de la Provincia del Neuquén, Argentina. Se detectó una correlación negativa entre depredación y producción de semillas. En los años de alta y baja producción de semillas, las tasas de depredación variaron entre 0,6 y 3,3\% y entre 13,0 y 20,6 \%, respectivamente. Entre años existe una variación en el patrón temporal de caída de semillas, con picos de caída en marzo y abril para 2002 y 2003, respectivamente. La tasa de depredación de semillas fue más baja y uniforme en el año de alta producción de conos pero no fue diferente entre sitios. En el año de baja producción de conos, la depredación aumentó durante la temporada, observándose la máxima depredación luego del pico de caída de semillas. La cachaña manipula las semillas con diferente eficiencia en años de alta y baja producción de conos, dejando caer menos semillas parcialmente dañadas en años de baja producción. Se discuten estos resultados en el contexto de la hipótesis sobre saciedad de predadores.

Palabras clave: depredación predispersión de semillas, Araucaria araucana, Enicognathus ferrugineus

\section{INTRODUCTION}

Masting cycles are widely thought to enhance plant reproduction because of their impact on seed predator numerical and functional responses (Janzen 1971, 1976, Silvertown 1980, Crawley \& Long 1995, Kelly \& Sork 2002). Predator populations may show a numerical response to seed crops, like the small mammal populations of north temperate oak forests that peak the year after large acorn crops (Ostfeld et al. 1996, Wolff 1996, Ostfeld \& Keesing 2000). According to the "predator satiation hypothesis", individual seed predators are limited by low seed abundance during intermast years, but become sated during mast years (Janzen 1976). Synchronous production limits predator impact even in the face of 
predator strategies that extend seed availability (Vander Wall 1990). High intermast predation rates curtail plant reproduction and low predation rates in mast years allow establishment of a new generation of recruits. This pattern of episodic reproduction may have long term consequences for forest population structure and management.

The pehuén, Araucaria araucana, is a dominant endemic of the southern Andes. It is a masting species whose intermittent and regionally synchronous seed production can carpet the forest with $300 \mathrm{~kg} \mathrm{ha}^{-1}$ of seeds at the peak of a masting cycle, more than 60 -fold the crop of some intermast years (Sanguinetti \& Kitzberger 2008). The pattern of its masting is consistent with both the predator satiation hypothesis and the hypothesis that pollination efficiency increases during mast years (Sanguinetti \& Kitzberger 2008).

Pehuén's primary pre-dispersal predators are Austral parakeets, Enicognathus ferrugineus, that remove maturing seeds directly from female cones (Finckh \& Paulsch 1995). After wind dispersal from the tree, the seeds are eaten by native small mammals, often in competition with domestic livestock and exotic wild boar, red deer and lagomorphs (Shepherd \& Ditgen 2005). Based on scant circumstantial evidence from the distribution of trees, Finckh \& Paulsch (1995) and Veblen (1982) speculated that Austral parakeets might disperse the seeds, but seed-carrying has not been observed. A few studies (Kon et al. 2005) have shown that seed predators exert selective pressure on tree reproductive synchrony, but no previous work has been directed at the interaction of pre-dispersal predation with pehuén masting cycles.

The aim of this study is to characterize parakeet seed predation in terms of the masting of A. araucana. The questions assessed are: (a) is parakeet seed predation consistent with the predator satiation hypothesis? Because predation rates should be lower when seed production is higher (Kelly \& Sork 2002), we expect predation to be inversely correlated with seed abundance; (b) do Austral parakeets change seed handling in response to seed production? According to foraging theory, mobile seed predators are likely to optimize foraging by adjusting search and handling to local seed production and phenology (Herrera \& Pellmyr 2002). Specifically, we would expect an increase in the efficiency of seed exploitation in response to low seed production.

\section{MATERIAL AND METHODS}

Seed production has been measured in Araucaria forests of southwestern Neuquén Province, Argentina since 2000 (Sanguinetti \& Kitzberger 2008). We selected forests between 1,200 to $1,400 \mathrm{~m}$ in elevation that were monitored in those studies and used their published cone-count estimates of seed production.

We estimated predation rates from samples of the seed fall collected in seed traps. Because geographic and supra-annual patterns of seed production and masting have been analyzed elsewhere (Sanguinetti \& Kitzberger 2008), our seed collection was designed to assess only monthly patterns of predation and seed fall as cones matured. To examine the effects of site, month and year on predation, we used data for 2002 and 2003 at three sites in Parque Nacional Lanín: one forest near Paso Tromen and two forests in the Rucachoroi basin. Seed production was low in 2002 and moderate-tohigh in 2003 (Sanguinetti\& Kitzberger 2008). Monthly predation rates were normalized with the arcsine square root transformation and totals of (damaged and whole) seeds collected were normalized with a natural log transformation. We used ANOVA, with months (February-May) within a year treated as repeated measures (Statistica 6.1®, Sokal\& Rohlf 1994, Quinn\& Keough 2002). There were 16 seed traps at Tromen in 2003 and eight seed traps in the other five samples. Following the advice of Quinn \& Keough (2002) for unequal sample sizes in the six site-year treatments, we analyzed all of the data collected and used type III sums of squares.

We used Pearson's product-moment correlation coefficient (Statistica 6.1®, Sokal\& Rohlf 1994, Quinn \& Keough 2002) to measure the association between whole-season predation rates and published estimates of seed production (Sanguinetti \& Kitzberger 2008). In addition to the data described above, we included data from Chiquilihuín for 2002 (eight seed traps) and from Tromen for 2004 (11 traps) and for 2005 (15 traps). 
Traps were constructed from 2 by $2 \mathrm{~m}$ squares of plastic shading fabric. The fabric was hung from a bamboo frame about $1.8 \mathrm{~m}$ off the ground so that it formed an inverted pyramid with a collecting area of approximately $3 \mathrm{~m}^{2}$. A $2 \mathrm{~L}$ plastic soda bottle attached at the low point helped to gather the seeds. Each seed trap was placed beneath a different female seed tree at least $60 \mathrm{~m}$ apart, moving traps between years to keep them in locations likely to catch seeds.

Seeds were collected from the traps throughout the main seed fall (normally late February through mid May). In 2004 seed collection continued through early June. In 2002-2004 traps were emptied approximately bi-weekly, but remoteness and difficulty of access precluded a rigid schedule. In 2005, we gathered the small seed fall of the entire season in a single sample. Where a collection period included days from more than one calendar month, we apportioned collections for analysis between months by simple interpolation. For example, if a collection interval included 7 days in March and 7 days in April, half of the collected seeds were analyzed as having fallen in each month.

The parakeets take seeds from Araucaria cones and eat them while sitting on adjacent branches. They do not eat the large seeds whole, but hold the seed scale in a foot as they take bites out of the seed itself. Seed scales are often dropped during this process. The characteristic marks of the parakeet's lower mandible on the seed scales allowed us to identify those that were damaged by parakeets (Finckh \& Paulsch 1995). In 2002 and 2003, damaged seeds were separated into three subjective damage categories: $<10 \%$ of seed eaten, 10 to $50 \%$ of the seed eaten, $>50 \%$ of the seed eaten. In other years, all parakeetdamaged seeds were placed in a single category. The predation rate is the number of damaged seeds as a percentage of the total number of seeds collected.

\section{RESULTS}

We collected 2,480 seeds in 2002 (4 sites) and 3,854 seeds in 2003 (3 sites) 1,000 seeds in 2004 (one site) and 146 seeds in 2005 (one site).

Parakeet predation rates were strongly correlated with seed production during the same year $(r=-0.90, \mathrm{P}=0.001, \mathrm{n}=9$, Fig. 1$)$. When seed production was high (16 to 20 cones per tree), predation rates ranged from 0.6 to $3.3 \%$. When production was low (2 to 6 cones per tree), predation rates ranged from 13.0 to $20.6 \%$.

Data from a total of 55 trap-years were used to analyze seed fall and predation rates (Table 1). There was a strong seasonal pattern to seed production that did not differ between sites ( $\mathrm{P}$ $\left.\left[\mathrm{F}_{\text {Month }}\right]<0.001, \mathrm{P}\left[\mathrm{F}_{\text {Month*Site }}\right]>0.05\right)$. Years differed significantly in the pattern of the seed fall (P $\left.\left[\mathrm{F}_{\text {Month*Year }}\right]<0.001\right)$. Seed fall peaked in March of 2002 and April of 2003 (Fig. 2A), but the shapes of the peaks differed between sites $\left(\mathrm{P}\left[\mathrm{F}_{\text {Month*Site*Year }}\right]<0.001\right)$. The effects of site and year on seed fall may simply result from our targeted trap placement rather than reflecting seed productivity.

Sites did not differ in predation rates $(\mathrm{P}$ $\left.\left[\mathrm{F}_{\text {Sites }}\right]>0.05\right)$ and there was no significant interaction between site and year $\left(\mathrm{P}\left[\mathrm{F}_{\text {Site*Year }}\right]\right.$ $>0.05)$. Predation rates in 2003 were both lower and more uniform than in $2002\left(\mathrm{P}\left[\mathrm{F}_{\text {Year }}\right]\right.$ $<0.001, \mathrm{P}$ [ $\left.\mathrm{F}_{\text {Month*Year }}\right]<0.001$, Fig. 2B). In 2002, seed fall peaked in March and predation rates peaked at $45 \%$ in April (Fig. 2B). There were significant interactions between month and site and between month, site and year ( $\mathrm{P}$ $\left[\mathrm{F}_{\text {Month*Site }}\right]<0.001, \mathrm{P}\left[\mathrm{F}_{\text {Month*Site*Year }}\right]<$ $0.001)$. Late in the 2002 season for example, predation dropped off sharply at Tromen, but stayed relatively high in the Rucachoroi forests.

The pattern of damage to seed scales differed in 2002 and 2003 (Table 2, $X^{2}=14.69$, $\mathrm{df}=2, \mathrm{P}<0.001)$. In the year of lower seed production, fewer seeds were released with less than $10 \%$ eaten (16 versus $29 \%)$ and the majority of the seeds were more than half eaten. In both years most seeds the parakeets attacked had more than $10 \%$ of the seed eaten (84\% in 2002, $71 \%$ in 2003).

\section{DISCUSSION}

Our results document the strong correlation of parakeet predation and seed production predicted by the predator satiation hypothesis. The $90 \%$ reduction in pre-dispersal predation during mast years could give a selective advantage to Araucaria genotypes producing seeds in synchrony. It is not clear whether 


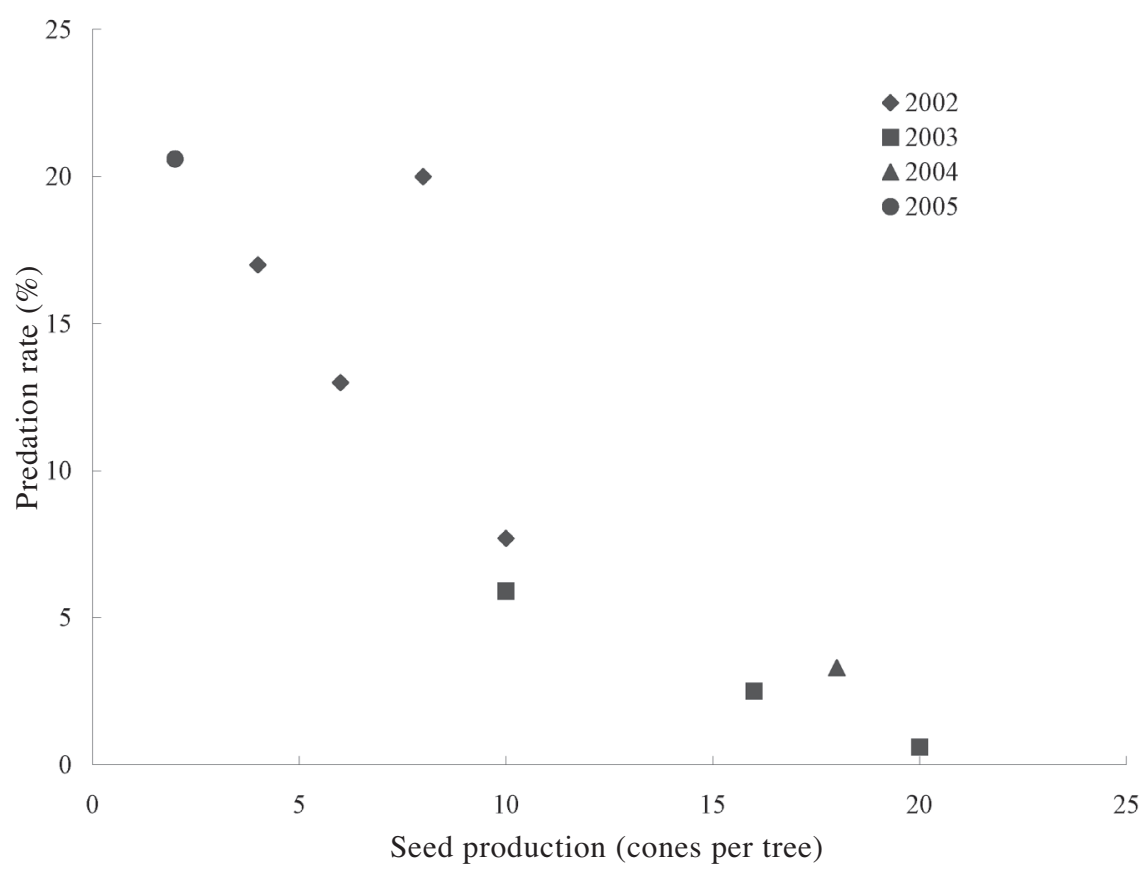

Fig. 1: A. araucana seed production and seed predation by Austral parakeets at four sites in southwestern Neuquén Province, Argentina. Each symbol plots the seed production (Sanguinetti \& Kitzberger 2008) and predation rate for all traps at a single site. Predation rate is the number of parakeet-damaged seeds as a percentage of the total seeds collected at the site.

Producción de semillas de A. araucana y la depredación por parte de la cachaña en el sudoeste de la Provincia de Neuquén, Argentina. Cada símbolo indica la producción de semillas (Sanguinetti \& Kitzberger 2008) y la tasa de depredación para todas las trampas al sitio. La tasa de depredación es el porcentaje de semillas dañadas por cachaña.

TABLE 1

Results of repeated measures ANOVA of A. araucana seed fall and predation by Austral parakeets. Monthly seed collections and predation rates were repeated measures for each seed trap. Total (damaged and undamaged) seeds collected was normalized with a natural log transformation. Percentage predation was normalized with an arcsine square root transformation

Resultados de ANOVA de medidas repetidas de la caída de semillas de A. araucana y de depredación por la cachaña. Colecciones de semillas mensuales y tasas de depredación eran medidas repetidas para cada trampa de semillas. Se normalizó el total de semillas (sanas y dañadas) por transformación al logaritmo natural. Se normalizó las tasas de depredación por transformación a la raíz cuadrada de arcoseno

\begin{tabular}{|c|c|c|c|c|c|c|c|c|}
\hline \multirow[t]{2}{*}{ Source of variation } & \multicolumn{4}{|c|}{ Seeds } & \multicolumn{4}{|c|}{ Predation } \\
\hline & $\overline{\text { F-value }}$ & df & P-value & & F-value & $\mathrm{df}$ & P-value & \\
\hline Intercept & 91.00 & 1 & $<0.001$ & $* * *$ & 90.1 & 1 & $<0.001$ & $* * *$ \\
\hline Site & 8.44 & 2 & 0.001 & $* * *$ & 0.1 & 2 & 0.876 & $\mathrm{~ns}$ \\
\hline Year & 1.05 & 1 & 0.311 & $\mathrm{~ns}$ & 49.3 & 1 & $<0.001$ & $* * *$ \\
\hline Site $\mathrm{x}$ year & 4.91 & 2 & 0.011 & $* * *$ & 0.2 & 2 & 0.805 & ns \\
\hline Error & & 49 & & & & 49 & & \\
\hline Month & 72.35 & 3 & $<0.001$ & $* * *$ & 23.0 & 3 & $<0.001$ & $* * *$ \\
\hline Month x site & 0.92 & 6 & 0.482 & $\mathrm{~ns}$ & 4.8 & 6 & $<0.001$ & $* * *$ \\
\hline Month x year & 42.62 & 3 & $<0.001$ & $* * *$ & 14.7 & 3 & $<0.001$ & $* * *$ \\
\hline Month $\mathrm{x}$ site $\mathrm{x}$ year & 5.22 & 6 & $<0.001$ & $* * *$ & 7.0 & 6 & $<0.001$ & $* * *$ \\
\hline Error & & 147 & & & & 147 & & \\
\hline
\end{tabular}


(A)

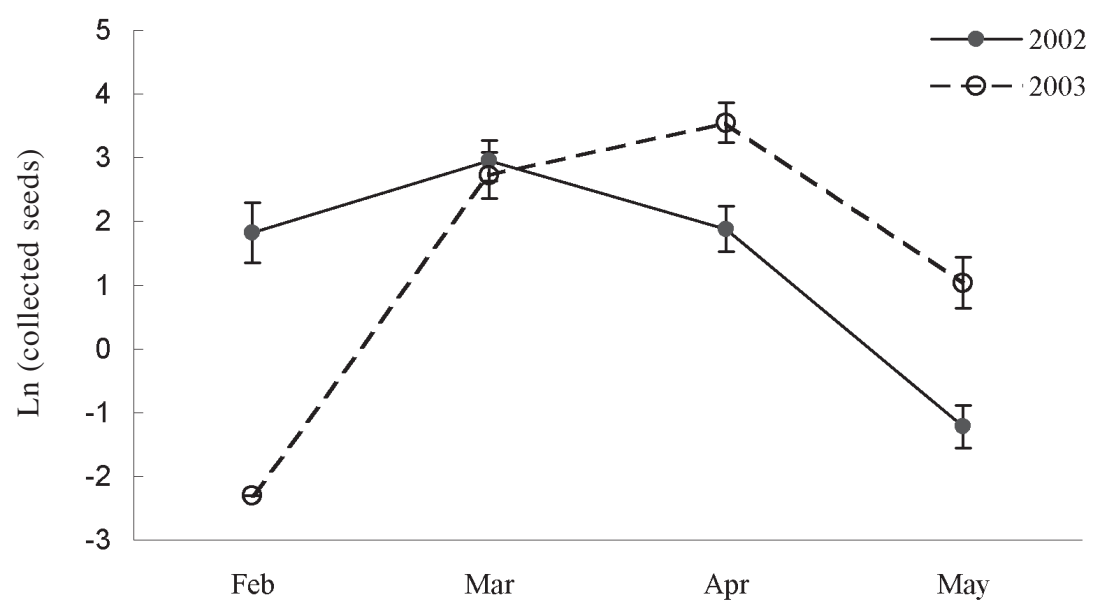

(B)

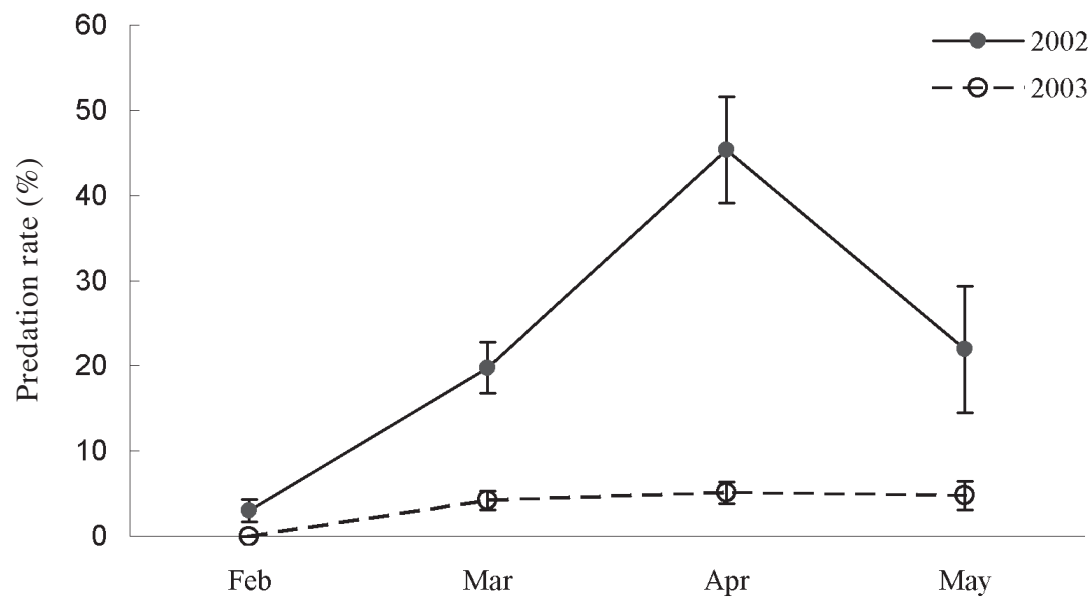

Fig.2: Seasonal patterns of A. araucana seed fall and seed predation by Austral parakeets in years with low (2002) and moderate-high (2003) seed production. (A) Symbol plots natural logarithm of the average seeds collected per trap at all sites; (B) symbol plots the average predation rate for all sites. Error bars represent standard errors.

Los patrones estacionales de caída de semillas de A. araucana y de depredación por la cachaña en años de producción baja (2002) y moderado-alto (2003). (A) El símbolo indica logaritmo natural del promedio de semillas colectadas por trampa en todos los sitios; (B) el símbolo indica el promedio de la tasa de depredación en todos los sitios. Las barras de error corresponden a errores estándar.

small intermast seed crops limit predator population size. Intermast predation rates of $20 \%$ do not themselves suggest food limitation, nor strong selection pressure for masting. Pre-dispersal predation by parakeets appears to be less important than postdispersal predation. Rates of post-dispersal predation by rodents and other animals exceed $70 \%$ during intermast years and predator satiation may occur during masting (Shepherd\& Ditgen 2005, Sanguinetti \& Kitzberger unpublished results).
Between mast and intermast years, there was a sharp, 10- to 30-fold, increase in parakeet predation intensity. Predation rates increased through the 2002 intermast season, reaching a high of $45 \%$ in the month after peak seed fall (Fig. 2). This suggests the parakeets switched to pehuén seeds as they became available, and exploited this diminishing resource late in the season. Other factors may also limit parakeet impact. The structure of the cone itself may place an upper limit on predation rates. Because the core of the cone softens as the seeds mature, 
removal of one seed scale by a parakeet often causes many others to fall to the ground from the cone. In addition, availability of suitable nesting cavities rather than food abundance may limit parakeet population size (Martin \& Eadie 1999, Bonar 2000, Bednarz et al. 2004).

Site, site-month and site-month-year influences on predation rates may reflect local geography, food availability and migration. In lenga (Nothofagus pumilio) forests, Austral parakeets are dietary opportunists that move up and down valleys to take advantage of locally available foods (Díaz 2004, Díaz \& Kitzberger 2006). Their exploitation of Araucaria forests undoubtedly involves local migration to and from nearby Nothofagus forests. They eat Araucaria pollen during the spring and early summer. As cones ripen in the autumn, parakeets return to Araucaria forests and consume seeds as long as they last.

Among the seeds parakeets attacked, the level of damage was inversely related to seed production (Table 2): attacked seeds had higher levels of damage when seeds were scarce and predation high. These results are consistent with a foraging optimization (Herrera \& Pellmyr 2002) in which search costs are reduced in intermast years by more intense exploitation of seeds that are found. Reduced handling of each seed, or reduced giving-up time, during peak years may result in less damage per seed but higher intake rates for parakeets. These changes in seed handling suggest Araucaria seeds have a high value for these birds.

\section{TABLE 2}

Level of Austral parakeet damage (\%) to A. araucana seeds in years of low (200) and moderate-high (2003) seed production. Parakeetdamaged seeds collected in seed traps were placed into three subjective damage categories

El nivel de daño por la cachaña a semillas de A. araucana en años de producción baja (2002) y moderado-alto (2003). Se agregó semillas dañadas por la cachaña en trés categorías subjectivas de daño

\begin{tabular}{lcc}
\hline Portion eaten & \multicolumn{2}{c}{ Year } \\
\cline { 2 - 3 } & 2002 & 2003 \\
\hline$<10 \%$ & 15.9 & 29.3 \\
$10-50 \%$ & 32.2 & 39.4 \\
$>50 \%$ & 51.8 & 31.3 \\
$\mathrm{n}$ & 295 & 99 \\
\hline
\end{tabular}

Correlation of seed predation and production has several population and community consequences beyond seed survival. First, because pre-dispersal predation shrinks the seed shadow and may reduce average dispersal distance (Janzen 1970, Vander Wall 2002), it can affect seedling and sapling success. While young A. araucana can persist suppressed in deep shade, they grow faster when they are dispersed out from under the mother's canopy (Finckh \& Paulsch 1995, Veblen et al. 1995). Parakeet predation would not just remove seeds from the recruitment pool; it could also increase the proportion of seedlings suffering from direct parental competition. Second, low mast-year seed predation should lead to episodic reproduction during years of peak seed crops. At Tromen, the highest seed production in the last 20 years (2000) was followed by establishment of a large cohort of new seedlings in the spring and summer of 2001 (Sanguinetti \& Kitzberger 2008). Such a seedling crop has not been seen since. This episodic reproduction produces a forest age structure with very uneven cohorts of trees. Lastly, pre-dispersal predation changes seed availability for other animals. High intermast predation increases the amplitude of fluctuations in the seed supply by reducing already low level of seeds reaching the forest floor. Heavy late-season intermast predation also shortens the season of seed availability for post dispersal predators. Parakeet predation may have important consequences for other animals in the seed food chain.

Araucaria araucana is an ancient species whose masting behavior evolved in the presence of extinct mammals, birds and/or reptiles. Our results suggest that its current predators may exert continued selection for this reproductive strategy.

\section{ACKNOWLEDGMENTS}

We thank the Delegación Regional Patagonia of Administración de Parques Nacionales for permission to work in Parque Nacional Lanín. This work was supported in part by a grant from the College of Liberal Arts of Mercer University, Macon Georgia. Help was also provided at all stages by personnel of Parque Nacional Lanín. We thank the Aigo Mapuche community for their cooperation. 


\section{LITERATURE CITED}

BEDNARZ JC, D RIPPER \& PM RADLEY (2004) Emerging concepts and research directions on the study of cavity-nesting birds: keystone ecological processes. Condor 106: 1-4

BONAR RL (2000) Availability of pileated woodpecker cavities and use by other species. Journal of Wildlife Management 64: 52-59.

CRAWLEY MJ \& CR LONG (1995) Alternate bearing, predator satiation and seedling recruitment in Quercus robur L. Journal of Ecology 83: 683-696.

DÍAZ JIS (2004) Predación predispersiva de Enicognathus ferrugineus en bosques de Nothofagus pumilio: patrones y efectos. Tesis de licenciatura, Centro Regional Universitario Bariloche, San Carlos de Bariloche, Argentina. $59 \mathrm{pp}$.

DÍAZ S \& T KITZBERGER (2006) High Nothofagus flower consumption and pollen emptying in the southern South American austral parakeet (Enicognathus ferrugineus). Austral Ecology 31: 759-766.

FINCKH M \& A PAULSCH (1995) The ecological strategy of Araucaria araucana. Flora 190: 365-382.

HERRERA CM \& O PELLMYR (2002) Plant-animal interactions: an evolutionary approach. Blackwell Publishing, Oxford, United Kingdom. 328 pp

JANZEN DH (1970) Herbivores and the number of tree species in tropical forests. American Naturalist 104: 501-528.

JANZEN DH (1971) Seed predation by animals. Annual Review of Ecology and Systematics 2: 465-492.

JANZEN DH (1976) Why bamboos wait so long to flower. Annual Review of Ecology and Systematics 7: 347 391.

KELLY D \& VL SORK (2002) Mast seeding in perennial plants: why, how, and where? Annual Review of Ecology and Systematics 33: 427-447.

KON H, T NODA, K TERAZAWA, H KOYAMA \& M YASAKA (2005) Evolutionary advantages of mast seeding in Fagus crenata. Journal of Ecology 93: 1148-1155.

MARTIN K \& JM EADIE (1999) Nest webs: a community-wide approach to the management and conservation of cavity-nesting forest birds. Forest Ecology and Management 115: 243-257

OSTFELD RS \& F KEESING (2000) Pulsed resources and community dynamics of consumers in terrestrial ecosystems. Trends in Ecology and Evolution 15: 232-237.

OSTFELD RS, CG JONES \& JO WOLFF (1996) Of mice and mast: ecological connections in eastern deciduous forests. Bioscience 46: 323-330.

QUINN GP \& MJ KEOUGH (2002) Experimental design and data analysis for biologists. Cambridge University Press, Cambridge, United Kingdom. 520 pp.

SANGUINETTI J \& T KITZBERGER (2008) Patterns and mechanisms of masting in the large-seeded southern hemisphere conifer Araucaria araucana. Austral Ecology 33: 78-87.

SHEPHERD JD \& RS DITGEN (2005) Human use and small mammal communities of Araucaria forests in Neuquén, Argentina. Mastozoología Neotropical (Argentina) 12: 217-226.

SILVERTOWN JW (1980) The evolutionary ecology of mast seeding in trees. Biological Journal of the Linnean Society 14: 235-250.

SOKAL RR \& J ROHLF (1994) Biometry: the principles and practice of statistics in biological research. Third edition W.H. Freeman and Company, New York, New York, USA. 881 pp.

VANDER WALL S (1990) Food hoarding in animals. University of Chicago Press, Chicago, Illinois, USA. 453 pp.

VANDER WALL S (2002) Masting in animal-dispersed pines facilitates seed dispersal. Ecology 83: 35083516.

VEBLEN TT (1982) Regeneraton patterns in Araucaria araucana forest in Chile. Journal of Biogeography 9: 11-28.

VEBLEN TT, BR BURNS, T KITZBERGER, A LARA \& R VILLALBA (1995) The ecology of the conifers of southern South America. In: Enright NJ \& RS Hill (eds) Ecology of the southern conifers: 120-155. Melbourne University Press, Melbourne, Australia.

WOLFF JO (1996) Populations of mast-eating rodents are correlated with the productions of acorns. Journal of Mammalogy 77: 850-856. 
